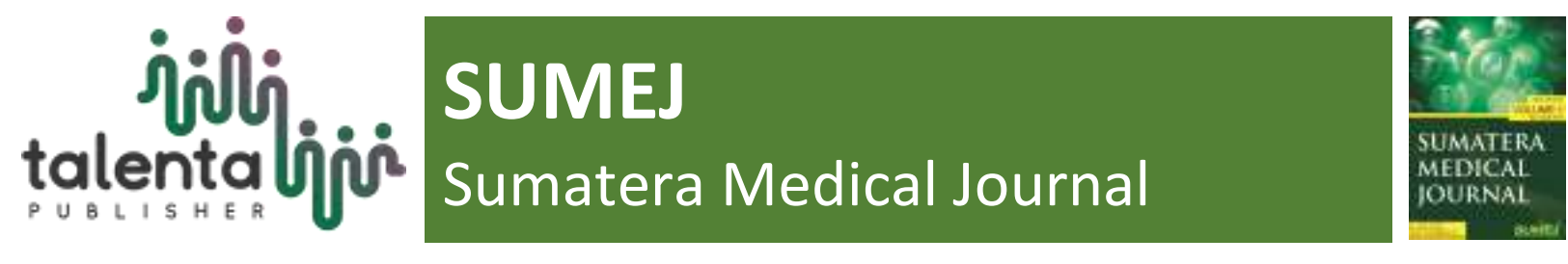

\title{
The Risk of Albuminuria to The Ischemic Acute Patient With or Without Metabolic Syndrome
}

\author{
A. Fresia, and Y. Anwar \\ Departement of Neurology, Faculty of Medicine, Universitas Sumatera Utara
}

\begin{abstract}
Stroke is not only a major cause of death, but also a leading cause of disability worldwide. Metabolic syndrome is one of the predictor of stroke since it has been linked to the development of atherosclerosis that will lead to cerebrovascular event. Albuminuria is known to be an indicator of endothelial dysfunction that is a major cause of cerebrovascular disease. In this study, 50 subjects of acute ischemic stroke consist of 25 subjects of acute ischemic stroke with metabolic syndrome and 25 subjects of acute ischemic stroke without metabolic syndrome. The ischemic stroke with metabolic syndrome population is significantly associated with increased risk of albuminuria 16 times higher than the ischemic stroke without metabolic syndrome $(\mathrm{OR}=16$, IK95\% $1.855-137.97$, $\mathrm{p}=0.002$ ). Subjects of ischemic stroke with metabolic syndrome is significantly associated with increased risk of albuminuria.
\end{abstract}

Keyword: Albuminuria, Ischemic Acute, Metabolic Syndrome

Received 23 August 2019| Revised 13 September 2019| Accepted 22 September 2019

\section{Introduction}

Stroke is an episode of neurological acute dysfunction caused by ischemic or bleeding for 24 hours or death. There is no sufficient evidence to be classified. Stroke ischemic is an episode of neurological dysfunction caused by cerebral focal infarction, spinal and retinal infarcts. Several risk factors related to stroke ischemic are divided into 2 categories: factor modified (such as hypertension and diabetes mellitus) and factor nonmodified (such as age and sex) (Sacco et al, 2013).

Albuminuria is the sign of general vascular disease and permeability increased of blood vessels that effect the large penetration of atherogenic lipo-protein particles to artery wall. Microalbuminuria is the sign of endothelia blood vessel damaging. Thus, the dysfunction of endothel in the brain connected with permeabilities membrane increased can be done by seeing the existence of permeability membrane increased the renal using the microalbuminiura examination (Mykkanen dkk, 1997)

\footnotetext{
${ }^{*}$ Corresponding author at: Faculty of Medicine, Universitas Sumatera Utara, Medan, Indonesia 
The increasing of urinary albumin levels are significant determinant of the occurrence CIMT from cardiovascular risk factors in type 2 DM patients. This significant relationship may refer to the pathophysiological relationship of atherosclerosis (Yuyun et al, 2004).

\section{Methodology}

\subsection{Place and Time}

The study was conducted at Department of Neurology FK - USU / RSUP H. Adam Malik Medan from March 2, 2016 to 10 October 2016.

\subsection{Subject Study}

The subject of study were taken from the population patient treated in the neurological inpatient ward, the determination of the study subjects was conducted according to the method of taking sample of consecutive sampling. This study used some instruments such as Computed Tomography Scan (CT Scan) head: CT Scan which used is X-Ray CT System, Hitachi brand W 450 series, then for the examination of profile lipid was measured by using Cobas 6000, the measurement of Blood glucose by using Cobas 6000, the measurement of Blood pressure with spigmomanometer, the Measurement waist circumference with a tape meter, and also the last measurement of Urine albumin was performed by using a dipstick with the URS-4SG brand.

1. All ischemic acute stroke patients who were treated in neurological inpatient room of RSUP. H. Adam Malik Medan have been performed with anamnesis, examination of neurology and examination CT scan head, were taken consecutively and fulfilling the criteria inclusion and exclusion, venous blood were taken $\pm 5 \mathrm{ml}$ after fasted for 8 hours to be examined triglyceride, HDL and fasting blood glucose. Triglycerides are group of water-soluble glycerol plasma esters. Divided into optimal levels (<150 mg / dl), borderline (150-199 mg / dl), high (200-499 mg / dl) and very high (> $500 \mathrm{mg} / \mathrm{dL}$ ) (Soegnado and Purnamasari, 2009). High dencity lipoprotein (HDL) is a lipoprotein produced by the liver and intestine and contains phospholipids and apolipoprotein (Fischbach, 2004). Divided into high levels ( $\geq 60 \mathrm{mg} / \mathrm{dl}$ ), low (<40 mg / dl) 
(Soegnado and Purnamasari, 2009). When urine were performed by using specimen urine random or when urine were $5 \mathrm{ml}$ and examined using dipstick for the value of urine albumin

The waist circumference is measured at the midpoint between the lower margin from rib and the part of iliac tops using the tap meter. The measurement of blood pressure performed with using standard spigmomanometer. Patient should be calm and performed after a 5-minute break.

\section{Result and Discussion}

The result of analy sis used Chi Square test showed that there was significant relationship between albuminuria with metabolic syndrome $(\mathrm{p}<0.001)$. The result OR value which means the subject with metabolic syndrome will be at risk if having albuminuria 16 times higher than subjects without metabolic syndrome.

Table I The Criteria for Metabolic Syndrome based on ATP III (2001)

\section{Criteria clinical}

\begin{tabular}{|c|c|}
\hline Weight & LP $\geq 102 \mathrm{~cm}$ male or $\geq 88 \mathrm{~cm}$ female \\
\hline Trigliserida & $\geq 150 \mathrm{mg} / \mathrm{dl}$ \\
\hline HDL & $<40 \mathrm{mg} / \mathrm{dl}$ male atau $<50 \mathrm{mg} / \mathrm{dl}$ female \\
\hline Blood Pressure & $\geq 130 / 85 \mathrm{mmHg}$ \\
\hline Fasting Glucose & $\geq 110, \mathrm{mg} / \mathrm{dl}$ (include patient DM) \\
\hline \multicolumn{2}{|c|}{$\begin{array}{l}\text { Dikutip dari : Soegnado, S.,dan Purnamasari, D. 2009. Sindrom metabolik. Dalam: } \\
\text { Sudoyo, A., Setiyohadi, B., Alwi, I., Simadibrata, M., Setiati, S. Buku ajar ilmu penyakit } \\
\text { dalam. Interna publishing. Jakarta. } 1865-1879\end{array}$} \\
\hline
\end{tabular}


Table II . Demographic characteristics of research subjects

\begin{tabular}{|c|c|c|}
\hline Characteristic Demographic & $\begin{array}{c}\text { Syndrom } \\
\text { Metabolic(+) } \\
(n=25)\end{array}$ & $\begin{array}{c}\text { Syndrom } \\
\text { Metabolic (-) } \\
(\mathrm{n}=25)\end{array}$ \\
\hline \multicolumn{3}{|l|}{ Gender, n (\%) } \\
\hline Male & $17(68)$ & $14(56)$ \\
\hline Female & $8(32)$ & $11(44)$ \\
\hline \multicolumn{3}{|l|}{ Age, Mean (SB), Year } \\
\hline$\geq 51$ years old & $19(76)$ & $19(76)$ \\
\hline$<51$ years olf & $6(24)$ & $6(24)$ \\
\hline \multicolumn{3}{|l|}{ Hypertension, n (\%) } \\
\hline Yes & $24(96)$ & $19(76)$ \\
\hline No & $1(4)$ & $6(24)$ \\
\hline \multicolumn{3}{|l|}{$\mathrm{DM}, \mathrm{n}(\%)$} \\
\hline Yes & $21(84)$ & $10(40)$ \\
\hline No & $4(16)$ & $15(60)$ \\
\hline \multicolumn{3}{|l|}{ Albuminuria, n(\%) } \\
\hline No & $1(2)$ & $10(20)$ \\
\hline Light & $10(20)$ & $15(30)$ \\
\hline Average & $8(16)$ & $0(0)$ \\
\hline Severe & $6(12)$ & $0(0)$ \\
\hline
\end{tabular}

Total of 21 people (84\%) subjects with metabolic syndrome had a history of DM and only 10 people (40\%) in the non metabolic syndrome group. In the SI group with SM, 1 person (2\%) no experience albuminuria, 10 people (20\%) light experienced albuminuria, 8 people (16\%) average experienced albuminuria and 6 people (12\%) severe experienced albuminuria while in the SI group without SM, 10 people (20\%) no experience albuminuria and 15 people (30\%) light experienced albuminuria.

Table III The risk of albuminuria to the ischemic acute patient with metabolic syndrome

\begin{tabular}{|c|c|c|c|c|c|c|}
\hline \multirow{2}{*}{$\begin{array}{l}\text { Syndrome } \\
\text { Metabolic }\end{array}$} & \multicolumn{2}{|c|}{ Albuminiura } & \multirow{2}{*}{$\mathrm{p}$} & \multirow{2}{*}{ OR } & \multirow{2}{*}{$\begin{array}{l}(95 \%) \\
\mathrm{IK})\end{array}$} & \multirow{2}{*}{$\mathrm{R}$} \\
\hline & Yes & No & & & & \\
\hline Yes & $\begin{array}{l}24 \\
(96)\end{array}$ & $\begin{array}{l}1 \\
(4)\end{array}$ & $0.002^{\mathrm{a}}$ & $16^{\mathrm{a}}$ & $\begin{array}{l}1.855- \\
137.97\end{array}$ & $0.435^{\mathrm{b}}$ \\
\hline No & $\begin{array}{l}15 \\
(60)\end{array}$ & $\begin{array}{l}10 \\
(40)\end{array}$ & & & & \\
\hline
\end{tabular}

${ }^{\mathrm{a}}$ Fisher's Exact ${ }^{\mathrm{b}}$ Spearman

From 25 subjects of acute ischemic stroke with metabolic syndrome was obtained 24 subjects (96\%) with albuminuria. Meanwhile, from 25 subjects with no metabolic syndrome was obtained 15 subjects $(60 \%)$ with albuminiura. 
The results of the analysis using Chi Square test showed there was a significant relationship between albuminuria with metabolic syndrome $(p<0.001)$. The resulting OR value is 16 which means subjects with metabolic syndrome will be at risk of having albuminuria 16 times greater than subjects without the metabolic syndrome. The correlation value obtained is 0.435 meaning that there is a moderate correlation between albuminuria with metabolic syndrome.

\section{Conclusion}

Based on the results of data analysis in this study, it could be concluded that ischemic acute stroke patients with metabolic syndrome had the 16 times bigger risk to have albuminuria compared to patient with ischemic acute without metabolic syndrome (OR $=16$, IK95\% $1.855-137.97)$

\section{REFERENCES}

[1] Kalla, S.N., \& Abhilash, K. Determinants of Metabolic Syndrome in Acute Ischemic Stroke patients. Sch. J. App. Med. Sci. 1(6):783-785. 2013

[2] Lee, H.O., Bak, H.J., Shin, J.Y \& Song, Y.M.Assosiation between metabolic syndrome and microalbuminuria in Ko-rean adult. 2015

[3] Sacco, R.L., Kasner, S. E., Broderick, S. P., Caplan, L. R., Cule-bras, A., Elkind, M. S.V., et al. An Up Date Defenition of Stroke For the 21st Century : A Statement For Healthcare Professionals from the American Heart Associ-ation/ American Stroke Association. Stroke: 44:2064-89.2013

[4] Soegnado, S.,dan Purnamasari, D. 2009. Sindrom metabolik. Dalam: Sudoyo, A., Setiyohadi, B., Alwi, I., Simadibrata, M., Setiati, S. Buku ajar ilmu penyakit dalam. Interna publishing. Jakarta. 1865-1879

[5] Yuyun, M.F., Khaw, K.T., Luben, R., Welch, A., Bingham, S., Day, N.E., et al. 2004. Microalbuminuria and stroke in a British population: the European Prospective Investigation into Cancer in Norfolk (EPIC-Norfolk) population study. Journal. Journal of internal medicine. 255: 247-256 